\title{
BRITAIN'S SCIENTIFIC SHRINES (I)
}

\author{
By Eng.-Captain EDGAR C. SMITH, O.B.E., R.N.
}

\begin{abstract}
FOR every traveller Great Britain presents a rich field for exploration; whatever his tastes, there is enough and to spare. Every village, every town, every city has its own tale to tell, while dispersed throughout the country are innumerable prehistoric sites, remains of Roman settlements, churches, cathedrals, castles, mansions, galleries and libraries. Societies and institutions, national and local, often with their own collections, abound, and with all this wealth awaiting the inquirer, there are agencies whose business it is to supply information of every kind, so that visitors to Britain in this Festival Year may become acquainted with the activities of our fellow men, both past and present, in their varied fields of endeavour. In this connexion it has been considered appropriate that attention should be directed to the homes and haunts of eminent men of science, their monuments and memorials, wherever they are to be found, thus providing information which may be of use to visitors with scientific leanings as they travel the countryside. Within the limits imposed, such a survey of the byways of science must necessarily be a partial one; but further notes will generally be found in guide books, county histories, the proceedings of local societies and the like, while it is only just to say that inquiries made to our public libraries seldom fail to receive the most careful consideration.

There are various ways in which such a survey of the byways of science as is proposed can be carried out; but that chosen is to deal with the counties in small groups, beginning with the southern counties, then with the eastern counties and so forth; but before travelling into the country, a few notes are given here about London, for it may be remarked that for the visitor to the Festival of Britain Exhibition, London itself offers perhaps the most varied feast of all. From the Tower of London in the east to Westminster Abbey in the west, in the City of London and the City of Westminster, and the adjacent districts, many a lane, many a street, many a building recalls an episode in the history of seience in Britain. The great County of London of to-day, created only in 1888 , is very different from the London of Harvey or Newton or Banks, and stretches from Woolwich to Hammersmith, embracing two cities, the Royal Borough of Kensington and no fewer than twenty-six other boroughs. It has absorbed parts of Kent, Surrey, Middlesex and Essex ; but it is the older London with which these notes are mainly concerned.
\end{abstract}

\section{LONDON}

The oldest scientific institution in London is the Royal College of Physicians, which has its headquarters in Pall Mall East. Its foundation in Tudor times was due to Thomas Linacre (1460?-1524), physician to Henry VIII, and its first home was in Linacre's house in Knight Rider Street, just south of St. Paul's Cathedral. In those days, old St. Paul's was still standing, and in it Linacre was buried and later commemorated by a memorial erected by Dr. John Caius (1510-73), the benefactor of Gonville Hall (which was renamed Gonville and Caius College), Cambridge. Tomb, memorial and cathedral were all destroyed by the Great Fire of 1666, but Linacre's fame is imperishable. The companion institution, the Royal College of Surgeons, which has its headquarters in Lincoln's Inn Fields, has a much shorter history; but it has its roots in the old corporations of Barber-Surgeons. In 1745, however, the barbers and surgeons became distinct corporations, and so arose the Masters, Governors and Commonalty of the Art and Science of Surgeons in London, the parent of the Royal College. One notable event in the history of the College was the acquisition of the anatomical collections of John Hunter (1728-93), whose death occurred with tragic suddenness at St. George's Hospital. Though no one can point to the spot where Linacre was buried, Hunter's remains lie in the north aisle of the nave of Westminster Abbey, whither they were trans. ferred at the expense of the Royal College of Surgeons through the extraordinary exertions of the naturalist Frank Buckland (1820-80), the son of the geologist William Buckland (1781-1856), sometime Dean of Westminster. In January and February 1859, Buckland spent many days in the vaults of St. Martinin-the-Fields, moving coffin after coffin until on February 22 he found Hunter's. Buckland was ill after his exertions, but recovered, and on March 28 attended the re-interment of the coffin in Westminster Abbey. Another famous man buried in St. Martin-in-the-Fields was Robert Boyle; but that was before the present church was built, and to-day Boyle is as one of those who have no memorial.

After the founding of the College of Physicians in 1518, the next scientific institution to arise in the City of London was Gresham College, which has now been active for more than three hundred and fifty years, and still provides courses of public lectures by its professors of astronomy, geometry, music, physic, civil law, divinity and rhetoric. Sir Thomas Gresham (1519?-1579), the Elizabethan magnate, before he died had given London its first Royal Exchange, and by his will he bequeathed to the City and the Mercers Company his mansion in Bishopsgate Street for a College. The bequest became available after his widow's death, and in 1596 Edward Brerewood (1565?-1613) began lecturing on astronomy, and Henry Briggs (1561-1630) on geometry. The College, which in different cireumstances might have blossomed out into a university, counted among its early professors Gunter, Rooke, Gellibrand, Greaves, Barrow, Hooke and Wren, and it was the meeting of some of these in the College, contemporary with meetings of others at Oxford, which led to the formation in 1660 of the Royal Society. The first recorded meeting of the Society took place in the College on November 28, 1660, and except for a brief period after the Great Fire, the College was the home of the Society for fifty years. Nothing of the old mansion remains to-day; but a visit to St. Helen's Church, Bishopsgate, in which is the monument to Gresham and the graves of some of the professors, will recall something of the old-world atmosphere of those seventeenth-century days. It was in the apartments of the Gresham professors that Boyle exhibited his air pumps, Wren talked on astronomy, Petty on shipping, and Wilkins on natural standards; that Evelyn became curator of insects, and Papin demonstrated his pressure cooker. Newton was elected a fellow and Hooke lived, worked and died there, and from it his remains were carried to St. Helen's Church. 
After about half a century of this close connexion between College and Society, difficulties arose with the Mercers Company, mainly through the bad state of the buildings, and the Society sought new quarters, thus beginning its journey westwards, first to Crane Court, Fleet Street, to premises of its own which it occupied from 1710 until 1780, then to Somerset House, in the Strand, to quarters provided by George III, and finally in 1857 to the fine mansion of the Earls of Burlingtion in Piccadilly, which had been purchased by the Government for $£ 140,000$. Many alterations and additions have been made to Burlington House, which to-day houses not only the Royal Society, but also the Society of Antiquaries, the Royal Academy, the Linnean Society, the Royal Astronomical Society, the Geological Society, the Chemical Society and the British Association for the Advancement of Science.

Of other scientific institutions in London with long histories, a word or two should be said about the Royal Society of Arts, which dates from 1754, and the Royal Institution, founded in 1799 , for they were formed, not so much with the object of furthering the progress of a particular science, but for contributing to the welfare of mankind. The former, known first as the Society of Arts, was founded "for the Encouragement of Arts, Manufacturers and Commerce", its promoter being William Shipley (1714-1803), a drawing master who established "Shipley's Academy" in the Strand. The Society held exhibitions of pictures before the Royal Academy, promoted agriculture before the Royal Agricultural Society, encouraged chemical research before the Chemical Society, and stimulated invention by medals and money prizes. In 1843 Prince Albert became its president, and the list of recipients of its Albert Medal rivals the list of the Copley medallists of the Royal Society, its roll of honour including the names of Pasteur and Madame Curie from France, Bunsen and Helmholtz from Germany, Marconi from Italy, and Edison and Michelson from America.

Even more than the Society of Arts, the Royal Institution owed its foundation to the spirit of philanthropy, for Count Rumford was ever for the betterment of the poorer classes, the improvement of their domestic appliances and the furtherance of their craftsmanship. Of the inauguration of this world-famous Institution, the fluctuations in its fortunes and the careers of its first professors and lecturers-Garnett, Young, Davy and Faraday--an account was given by Dr. Bence Jones in his book "The Royal Institution", published in 1871. For a historian of science it is as fascinating reading as Weld's "History of the Royal Society", published in 1848. By 1871, Faraday had boen dead four years, but his mantle had fallen on the shoulders of John Tyndall, and their work and that of their successors, Frankland, Gladstone, Rayleigh, Dewar, Bragg and others, form one of the brightest pages in the history of science in Great Britain. But it is a mistake to think of the Royal Institution solely in terms of science, for its lecture theatre has resounded, and still resounds, with the voices of men distinguished in many other spheres. Sir Benjamin Thompson, Count von Rumford (1753-1814), who was knighted by George III and made a Count of the Holy Roman Empire by the Elector of Bavaria, and was dubbed by Gibbon "Mr. Secretary-Colonel-AdmiralPhilosopher" Thompson, began life as a British colonial, having been born in North Woburn, Massachusetts, and first came to England when twenty- three years of age. It was this that led Prof. Florian Cajori, of California, in his "History of Physics", to write: "It is pleasant to contemplate that while the Royal Institution was founded by an American, the Smithsonian Institution in Washington owes its origin to an Englishman".

To another category of scientific institutions belong our great national museums. In its early days the Royal Society formed collections of which Nehemiah Grew in 1681 published a catalogue of 435 pages and 31 plates dedicated to Daniel Colwall, the founder of the collections. Apparently, one specimen described by Grew, "a frontlet of the West African dwarf buffalo (Syncerus nanus)", still survives in the British Museum (Natural History). There were other collections in private houses and even in some London coffee houses ; but our modern museums begin with the purchase by the Government of the library and collections of Sir Hans Sloane, and the opening of the British Museum in 1753. Among these collections were birds, insects, fossils, minerals and a herbarium preserved in 334 large folio volumes. The present Natural History Museum, completed in 1880, at South Kensington, is still an integral part of the British Museum, which will soon be commemorating its bicentenary.

At South Kensington are also the Victoria and Albert Museum, which is descended directly from a museum of manufactures founded after the Great Exhibition of 1851, the Science Museum-the national museum of science and industry-and the Geological Museum, the direct descendant of the Museum of Practical Geology opened in 1851 in Jermyn Street. Histories of science concern themselves mainly with the great discoverers and pioneers ; but the most eursory glance at the catalogues of these museums with their millions of exhibits shows how the progress of science is indebted to thousands of men and women who in one way or another, by their studies, their travels, their collecting and their writings, have added their contributions to the great structure of science of to-day; and in the museums are found some of their noble gifts to the country.

An almost forgotten chapter in the scientific annals of London centres around the old coffee houses and taverns. At the Rainbow Coffee House in Watling Street in 1721 was a botanical society, presided over by the German professor John James Dillenius; to the Grecian Coffee House in Devereux Court, Strand, the fellows of the Royal Society would adjourn after their discussions in Crane Court. Childs, Slaughters, the Bedford and the Salopian coffeo houses all figure in the memoirs of the eighteenth century, as also do the Chapter Coffee House, in St. Paul's Churchyard, where a chemical club used to meet, and the London Coffee House, Ludgate Hill, where Priestley presided over a social and philosophical club. Notable among such gatherings were those of the old Royal Society Club, known in its early days as "the Club of the Royal Philosophers". Watt was entertained at one of its gatherings by Cavendish, Blagden and Smeaton, and afterwards wrote: "Never was turtle eaten with greater sobriety and temperance or more good fellowship".

Wander where he will in London, the visitor is never far from some spot with scientific associations. In the Tower, Flamsteed made observations before Greenwich Observatory was built; at the Mint, close by, Newton, Sir John Herschel and Thomas Graham all held the mastership, while Faraday and Tyndall made investigations for Trinity House. In the 
old Charterhouse, now rising from the ruins of war, Stephen Gray, the first of all Copley medallists, made his remarkable electrical experiments when he was well over seventy. Not far away, in Newgate Street, stood Christ's Hospital, the 'Blue Coat School', now finely housed at Horsham, Sussex. In the seventeenth century it had a mathematical school, two of the scholars from which went to Russia with Peter the Great; one was murdered and of the other nothing is known.

All around Fleet Street were the shops of the clock and instrument makers, and in St. Bride's Church was a memorial to Dr. Charles Wells, known for his investigations on dew. St. Paul's Cathedral is not only the resting-place of Mylne, who built West. minster Bridge, and Rennie, who designed old Waterloo Bridge and London Bridge, but also the great Sir Christopher Wren himself. Not so many years after his death, experiments were made in the Cathedral with falling bodies released from the dome.

Many a house; many a street having associations with the scientific worthies of old London, have disappeared; but a visitor, if he wishes, can make a pilgrimage with the aid of a "List of Houses of Historical Interest in London Marked by Memorial Tablets", obtainable from the Record Keeper of the London County Council.

No scientific pilgrimage in London, however, would be complete without a visit to Westminster Abbey, where among the hundreds of tombs, statues, tablets and other memorials are some forty to fifty to men of science of the past three hundred years. The first of these to be buried in the Abbey was Sir Robert Moray (d. 1675), the earliest president of the Royal Society ; the last was Lord Rutherford, whose ashes were buried on October 25, 1937, in the nave close to the graves of Newton, Sir John Herschel, Kelvin and Darwin. Not far from these in the centre of the nave lie Telford, Robert Stephenson, Tompion, and George Graham. In the north aisle of the choir near by is a remarkable group of tablets and medallions to Lord Lister, A. R. Wallace, Darwin, Sir George Stokes, Joule, Sir William Hooker, John Couch Adams and Sir William Ramsay. With a copy of the official guide to the Abbey, it is easy enough to find any particular grave or monument or memorial window. Chantrey's $£ 6,000$ statue of Watt is to be found in St. Paul's Chapel, Baily's statue of Telford in St. Andrew's Chapel, where also are the memorials to Davy, Thomas Young, Sir James Young Simpson, Dr. Matthew Baillie and to the third Baron Rayleigh (1842-1919), "an unerring leader in the advancement of natural knowledge". Periodically there is a somewhat half-hearted demand that some of the many memorials in the Abbey should be removed; but it was Dean Stanley who wrote that Westminster Abbey is endeared to the nation not so much that it is the scene of the coronations or the sepulchre of kings, but "that it is the resting-place of famous Englishmen from every rank and creed, and every form of mind and genius". There is no "Valhalla' like the Abbey anywhere else in the world, and not even the Père la Chaise Cemetery in Paris surpasses it in its interest for the man of science. There are scores of famous British men of science and engineers-such as Roger Bacon, Francis Bacon, Gilbert, Rry, Harvey, Cavendish, Priestley, Huxley, Owen, Gilbert White, William Herschel, George Stephenson and Smeaton-whose memorials are not in the Abbey, and it will be one of the objects of this survey to show where they are to be found.

\section{DECLINE AND DEATH OF BACTERIAL POPULATIONS* \\ By SIR CYRIL HINSHELWOOD, F.R.S.}

\section{Introduction}

GROM certain points of view the bacterial cell may advantageously be regarded as the seat of a complex pattern of chemical reactions, the rules of combination of which determine many of the characteristic properties ${ }^{1}$. The enzyme reactions constitute a sort of production-line; the functioning of the enzymes must be linked with their own synthesis, and the building of proteins and of nucleic acids is interrelated in such a way that each appears dependent on the other ${ }^{2}$. A multiplicity of simple substrates are utilizable by the cell, but lags and delays attend the switching from one to the other. Similar lags occur before synthesis is resumed after an interruption, since inactivated enzymes require to be repaired and the intermediate metabolites which pass from one section to another of the productionline have to attain once more their proper concentrations. When an adaptive switch from one set of growth conditions to another is imposed, the enzymatic constitution of the cell undergoes changes of limited amplitude, short of mutations but important in themselves. Indeed, there is good reason to believe that there is an automatic adjustment to that set of proportions which will allow the reaction pattern corresponding to an optimum growth-rate.

When the growth of a culture stops and the cells cease to multiply, there is no reason to suppose that the machine is very much more quiescent than when visible autosynthesis is proceeding. Oxidations, deaminations and other specific enzyme reactions are brought about readily by suspensions of non-growing cells; when actual increase of mass ceases at the end of the logarithmic phase, transformation of ribose nucleic acid into deoxyribose nucleic acid seems to continue for a time ${ }^{3}$; and indeed the whole trend of modern experiments on the exchange of radioactive tracer elements seems to show that the making and unmaking of the cell material continues at a lively rate in most living cells even when the balance of these two processes gives no net increase in substance $e^{4}$ Although linked for the purposes of growth, individual enzyme reactions occur to some extent autonomously, since they are called forth by the provision of the appropriate substrate more or less in isolation.

When, however, bacterial cultures are not given opportunity for renewed growth, the population tends to decline, the death-rate of the cells being, of course, accelerated by adverse circumstances such as the presence of toxic substances. 'The law of decline not infrequently approximates to the exponential form $n=n_{0} \exp (-\lambda t), n_{0}$ being the initial number, $n$ the number at time $t$ and $\lambda$ a constant. This law has occasioned much discussion ${ }^{5}$. Taken as exact, it implies that the death of a cell is governed by a chance event independent of the previous history; and various authors have regarded this event as an accidental encounter between some sensitive component of the cell and a molecule of the toxic agent. In particular, the lethal effects of radiation have been interpreted in terms of encounters between quanta and sensitive targets in the structure of the living material ${ }^{6}$.

*A sequel to "Chemistry and Bacteria" (Nature, Dcc. 30, 1950). 